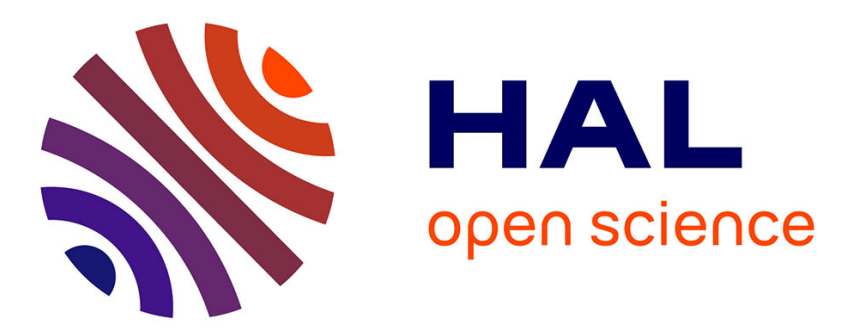

\title{
Determination of atrazine and degradation products in Luxembourgish drinking water: origin and fate of potential endocrine disrupting pesticides
}

Torsten Bohn, Emmanuelle Cocco, Laurent Gourdol, Cédric Guignard, Lucien Hoffmann

\section{To cite this version:}

Torsten Bohn, Emmanuelle Cocco, Laurent Gourdol, Cédric Guignard, Lucien Hoffmann. Determination of atrazine and degradation products in Luxembourgish drinking water: origin and fate of potential endocrine disrupting pesticides. Food Additives and Contaminants, 2011, pp.1. 10.1080/19440049.2011.580012 . hal-00712357

\section{HAL Id: hal-00712357 \\ https://hal.science/hal-00712357}

Submitted on 27 Jun 2012

HAL is a multi-disciplinary open access archive for the deposit and dissemination of scientific research documents, whether they are published or not. The documents may come from teaching and research institutions in France or abroad, or from public or private research centers.
L'archive ouverte pluridisciplinaire HAL, est destinée au dépôt et à la diffusion de documents scientifiques de niveau recherche, publiés ou non, émanant des établissements d'enseignement et de recherche français ou étrangers, des laboratoires publics ou privés. 


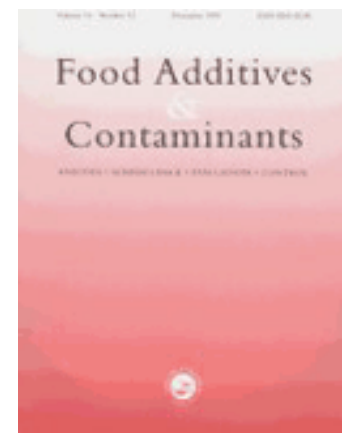

\section{Determination of atrazine and degradation products in Luxembourgish drinking water: origin and fate of potential endocrine disrupting pesticides}

\begin{tabular}{|c|c|}
\hline Journal: & Food Additives and Contaminants \\
\hline Manuscript ID: & TFAC-2011-009.R1 \\
\hline Manuscript Type: & Original Research Paper \\
\hline $\begin{array}{r}\text { Date Submitted by the } \\
\text { Author: }\end{array}$ & 28-Mar-2011 \\
\hline Complete List of Authors: & $\begin{array}{l}\text { Bohn, torsten; CRP - Gabriel Lippmann, Environment and Agro- } \\
\text { Biotechnologies } \\
\text { Cocco, emmanuelle; CRP - Gabriel Lippmann, Environment and } \\
\text { Agro-Biotechnologies } \\
\text { Gourdol, Laurent; CRP - Gabriel Lippmann, Environment and Agro- } \\
\text { Biotechnologies } \\
\text { Guignard, Cédric; CRP - Gabriel Lippmann, Environment and Agro- } \\
\text { Biotechnologies } \\
\text { Hoffmann, Lucien; CRP - Gabriel Lippmann, Environment and Agro- } \\
\text { Biotechnologies }\end{array}$ \\
\hline Methods/Techniques: & LC/MS, Chromatographic analysis \\
\hline Additives/Contaminants: & Pesticides, Herbicides, Hormones \\
\hline Food Types: & Water \\
\hline Abstract: & $\begin{array}{l}\text { Several pesticides have been hypothesized to act as endocrine } \\
\text { disrupting compounds, exhibiting hormonal activity and perturbing } \\
\text { normal physiological functions. Among these, especially s-triazine- } \\
\text { herbicides have received increased attention. Atrazine is, despite } \\
\text { being banned in many countries, including the EU (2004), still the } \\
\text { world's most widely used herbicide. Despite its discontinued use, } \\
\text { considerable concentrations of atrazine and its degradation } \\
\text { products, mainly desethylatrazine (DEA) and deisopropylatrazine } \\
\text { (DIA), are still found in the environment, including drinking water } \\
\text { sources. The aim of this investigation was to study concentrations }\end{array}$ \\
\hline
\end{tabular}




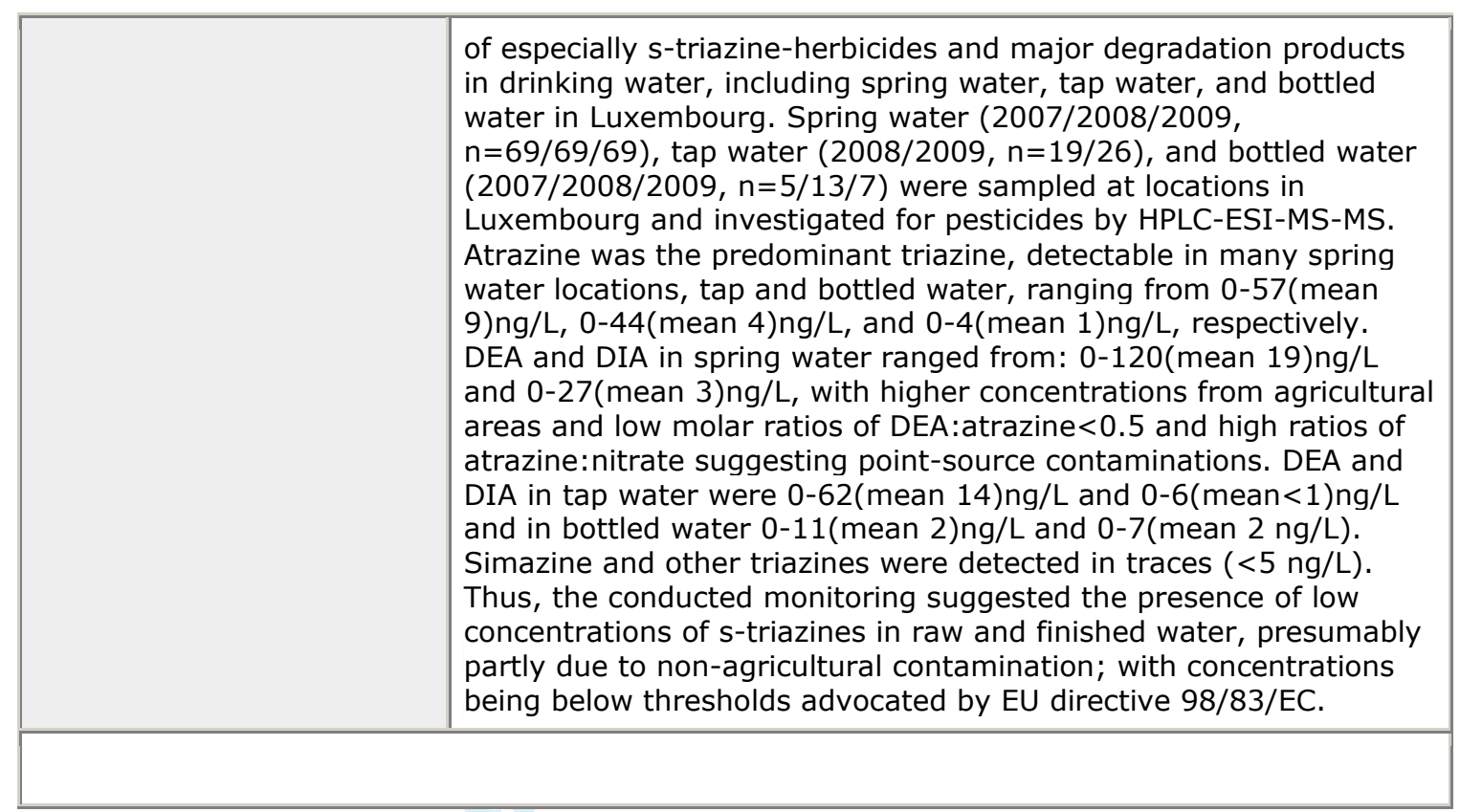

\section{SCHOLARONE ${ }^{\text {m }}$} Manuscripts 
1 Endocrine Disrupting Pesticides in Water

2

3 Determination of atrazine and degradation products in Luxembourgish

4 drinking water: origin and fate of potential endocrine disrupting pesticides

5

6 T. Bohn*, E. Cocco, L. Gourdol, C. Guignard, L. Hoffmann

7

8 Centre de Recherche Public - Gabriel Lippmann, Department Environment and Agro-

9 Biotechnologies, 41, rue du Brill, L-4422 Belvaux, Luxembourg

10

11 *Correspondence : Torsten Bohn, Centre de Recherche Public - Gabriel Lippmann

$12 \quad$ E-mail : bohn@lippmann.lu

13

Phone: (+352)470261480

$14 \quad$ Fax : $(+352) 470264$

15

16

17 Abstract

18 Several pesticides have been hypothesized to act as endocrine disrupting compounds,

19 exhibiting hormonal activity and perturbing normal physiological functions. Among these,

20 especially s-triazine-herbicides have received increased attention. Atrazine is, despite being

21 banned in many countries, including the EU (2004), still the world's most widely used

22 herbicide. Despite its discontinued use, considerable concentrations of atrazine and its

23 degradation products, mainly desethylatrazine (DEA) and deisopropylatrazine (DIA), are still

24 found in the environment, including drinking water sources. The aim of this investigation was

25 to study concentrations of especially s-triazine-herbicides and major degradation products in 
26 drinking water, including spring water, tap water, and bottled water in Luxembourg. Spring by EU Directive 98/83/EC. atrazine ratio, nitrate, 2,6-dichlorobenzamide.

Keywords : s-triazine herbicides, atrazine degradation products, tap and spring water, DEA:

\section{Introduction}

Endocrine disrupting compounds (EDC) are molecules exhibiting hormonal or antihormonal activities, thus interacting and potentially perturbing normal physiological functions. These include natural compounds, such as mycotoxins, e.g. zearalenone (Mantovani et al., 2009; Giraud et al., 2010) and soy isoflavonoids (Cederroth et al., 2010), and man-made chemicals such as pharmaceuticals (Pailler et al., 2009) and polychlorinated biphenyls (Lasserre et al., 
51 pesticides, including e.g. herbicides, fungicides, and insecticides. As these compounds have been released on purpose and are often in direct contact with the future food product, great prudence in their choice, way of application and concentration has to be maintained.

Nevertheless, with the increased research on EDC, including pesticides, several compounds have been hypothesized to impact the human hormonal system. Among pesticides, especially the s-triazine-herbicides such as terbutylazine, cyanazine, simazine and atrazine have achieved much attention in recent years, even though they have been used since the 1950ties (Ribaudo and Bouzaher, 2010). Despite the strict classification of atrazine (2-chloro-4ethylamino-6-isopropylamine-s-triazine) as an EDC has been discussed (Solomon, 2009), it has been suggested to inflict the central nervous system (Coban and Filipov, 2007; Rodriguez et al., 2005), the endocrine system (Rayner et al., 2004; Hayes et al., 2006) and the immune system (Rowe et al., 2008; Brodkin et al., 2007), effecting the reproductive health of rats (Kniewald et al., 2000), pigs (Betancourt et al., 2006), and amphibians (Hayes et al., 2006), fostering feminization in the latter (Hayes et al., 2010). However, data on the impact on mammals and particularly humans is scant and effects remains unclear (Solomon, 2009).

Nevertheless, atrazine is still the most used herbicide in many countries and possibly worldwide (Thurman and Scribner, 2008). It is used for weed removal, especially against broadleaf and grassy weeds, employed in agricultural but also in urban areas such as in private gardens, on railway tracks, or other weed control programs. Atrazine possesses a high groundwater ubiquity score (GUS) of ca. 3.6 (Vogue et al., 1994) and thus a high potential for groundwater contamination. In fact, the major way of human intake for this pesticide is via water (Bray et al., 2008). In the EU, usage of atrazine was abandoned in 2004 following general precautionary principles; however, significant concentrations can still be found in the 
76 environment such as in groundwater and surface water (Loos et al., 2010; Kuster et al., 2010; 77 Planas et al., 2006; Administration de la Gestion de l'Eau, 2005), often in concentrations 78 above the $0.1 \mu \mathrm{g} / \mathrm{L}$ limit set by the EU directive 98/83/EC. In addition to raw water, atrazine 79 has been detected in finished (tap) water, up to $60 \mu \mathrm{g} / \mathrm{L}$ in the US (Wu et al., 2010), while 80 concentrations in bottled water are generally assumed to be much lower, due to filtration steps 81 through activated carbon during production.

83 Despite its persistence, atrazine has been shown to undergo degradation in the soil due to 84 bacterial activities. These breakdown products include mainly the comparatively stable 85 desethylatrazine and deisopropylatrazine (Papiernik and Spalding, 1998; Jason et al., 2010), 86 which have likewise been detected in groundwater (Shomar et al., 2006; Loos et al., 2010), 87 and tap water (Gfrerer et al., 2002), however, the s-triazine ring can be further hydroxylated 88 (Krutz et al., 2010) and finally cleaved (Scribner et al., 2005). However, whether and to what 89 extent these breakdown products possess endocrine disrupting functions is not entirely clear, 90 albeit it is being assumed for DEA and DIA (Ralston-Hooper et al., 2009).

While data on s-triazines, especially atrazine content in spring water and tap water has been reported for some European countries, such as for France (Brignon, 2007; Mirgain et al., 1993; Ministère de la Santé et des Solidarités, 2005) and Germany (Leistra and Boesten,

96 published for Luxembourg. Thus, the aim of this study was to investigate pesticide, especially

97 s-triazine contamination of individual spring water locations in Luxembourg, to verify 98 whether contamination is related to agricultural activities, and to finally determine 99 concentrations in finished drinking water (tap water) and bottled water in Luxembourg. 
101 Material and Methods

102 Reagents and Standards

103 Unless otherwise stated, all chemicals were of analytical grade or superior. All herbicide

104 standards including the s-triazine herbicides atrazine, simazine, terbuthylazine, sebuthylazine, 105 cyanazine, and hexazinon, and the atrazine degradation products desethylatrazine and 106 deisopropylatrazine, the urea herbicides isoproturon, chlortoluron, monolinuron, 107 methabenzthiazuron, metoxuron, diuron, linuron, and metobromuron, the chloroacetanilide 108 herbicides metazachlor and metolachlor, and 2,6-dichlorobenzamide (BAM, Figure 1), a 109 breakdown product of the herbicide dichlobenil, were obtained from LGC Promochem 110 (Molsheim, France). Methanol, acetone, and acetonitrile were procured from Biosolve 111 (Valkenswaard, The Netherlands).

112

113 Sampling campaigns

114 Several campaigns were carried out in the frame of this study:

115 a) Spring water: 69 springs in the Luxembourg City area from sandstone aquifer, the 116 major aquifer in Luxembourg (for a detailed description, see Gourdol et al., 2010), 117 were monitored between summer 2007 and spring 2009, with a total of 10 collection 118 campaigns (July/August 2007, November 2007, January 2008, March 2008, May 119 2008, June/July 2008, September 2008, October/November 2008, January 2009, 120 March 2009, Figure 2). All these springs are involved in the water drinking supply of 121 Luxembourg City and were revisited during the entire period to compare changes in 122 individual springs. These springs can be grouped into 9 distinct hydrogeological 123 zones whose recharge areas covered a range of different surface usages including 124 forest, cropland, urban areas and grassland (Figure 2). For each individual sampling, 125 ca. $2 \times 500 \mathrm{~mL}$ of water were sampled in pre-washed glass bottles (analyses of 
126 pesticides) or polyethylene bottles (analysis of nitrate), and stored at $4^{\circ} \mathrm{C}$ until analysis (conducted within $48 \mathrm{~h}$ of collection). During the sampling campaigns, spring discharges were also evaluated.

b) Tap water: Luxembourgish tap water from various locations in Luxembourg $(n=34$, from $n=28$ different locations, analyzed in duplicate) in spring 2008 and spring 2009 were analyzed (Figure 3). For this purpose, tap water from private households was collected after having let the water tap open for at least 2 minutes, and then approx. 1.5 $\mathrm{L}$ were collected in glass bottles and stored at $4^{\circ} \mathrm{C}$ until analysis. The campaign focused on southern Luxembourg with its higher population and population density.

c) Bottled water: A sampling of various bottled water varieties sold in Luxembourg in summer 2007, 2008 and 2009, with a focus on locally produced water samples $(n=25$ in total, with $\mathrm{n}=15$ from Luxembourg), analyzed in duplicate, was procured. Both sparkling $(n=4)$ and plain water $(n=21)$ was included, a total of 10 different brands was investigated. Samples were procured in local supermarkets (CACTUS S.A., CORA), which constitute the most visited chains in Luxembourg.

\section{Pesticide extraction and concentration}

143 The water pre-concentration was realized similar as described earlier (Trenholm et al., 2006)

144 using an automatic SPE workstation (Autotrace SPE workstation, Caliper, Hopkinton, MA, 145 USA), and cartridges containing a vinylpyrolidone-divinylbenzene copolymer (oasis HLB, $146200 \mathrm{mg}$, Waters, Elstree, UK). For this purpose, SPE cartridges were preconditioned with 10 $147 \mathrm{~mL}$ methanol followed by $10 \mathrm{~mL}$ of water. Then, $500 \mathrm{~mL}$ of water was loaded at $10 \mathrm{~mL} / \mathrm{min}$. 148 Pesticides were then eluted 2 times with $5 \mathrm{~mL}$ of methanol. Samples were then evaporated to 149 near dryness with a Speedvac concentrator (Heto, Denmark) and reconstituted in ca $0.5 \mathrm{~mL}$ of 150 water:acetonitrile 80/20 (v/v) and stored at $4{ }^{\circ} \mathrm{C}$ until analysis. 


\section{HPLC-MS-MS detection}

153 Detection and quantification was achieved by HPLC coupled to a tandem mass spectrometer 154 (LC-MS/MS, Dionex Ultimate 3000, Sunnyvale CA, USA, together with an AB Sciex API 1553200 mass spectrometer, Concord, ON, Canada), using electrospray ionization (ESI) in 156 positive mode and multiple reaction monitoring (MRM), similar as described earlier (Baker et 157 al., 2000; Panuwet et al., 2008). An Acclaim 120 C-18 column (3 $\mu$ m, 2.1 x 100 mm, Dionex) 158 was used at $40^{\circ} \mathrm{C}$ with a mobile phase consisting of water containing $0.1 \%$ formic acid (FA) 159 (solvent A) and acetonitrile containing $0.1 \%$ FA (solvent B). The gradient started at $20 \%$ of B 160 for 3 min and was changed to $40 \%$ B until 12 min, to $90 \%$ B until 15 min, to $100 \%$ B until $16115.5 \mathrm{~min}$, remaining at $100 \%$ until $18 \mathrm{~min}$, decreased to $20 \% \mathrm{~B}$ at $18.5 \mathrm{~min}$ and stayed at $20 \%$ 162 B until $20 \mathrm{~min}$. Flow rate was $0.25 \mathrm{~mL} / \mathrm{min}$, injection volume was $25 \mu \mathrm{L}$. Quantification was 163 achieved by using external standards and external calibration curves, typically in the range of $1641 \mathrm{ng} / \mathrm{L}$, and deemed acceptable if $\mathrm{R}$ exceeded 0.98. For the MS-MS parameters, vaporizer 165 temperature was set to $600^{\circ} \mathrm{C}$. The capillary voltage was $5 \mathrm{kV}$. Nebulizer and turbo gas were 166 set at 55 and 50 psig, curtain and collision gas at 15 and 5 psig, respectively. Collision offset 167 voltages were individually optimized for each component (Table 1). The retention time, 168 parent mass, and quantifier ion for each pesticide are displayed in Table 1.

$170 \quad$ Nitrate

171 Nitrate was assessed from water originating from Luxembourg-City springs in order to assess

172 agricultural usage of the land (i.e. coming from fertilizer usage) and to compare results with 173 pesticide concentrations. Nitrate in spring water was measured by ion chromatography, 174 following the manufacturer's suggestion (Dionex Corporation, 1991). In short, samples were 175 filtered through an IC acrodisc Gelman LC13 $0.45 \mu \mathrm{m}$ filter (Pall Gelman, Dreieich, 
176 Germany) and separated by ion chromatography employing a DX 500 (Dionex) and a 177 AS12A-4 mm column, using a micromembrane suppressor (ASRS-Ultra, Dionex) and a 178 gradient eluent of $2.7 \mathrm{mM} \mathrm{Na} \mathrm{CO}_{3} / 3.0 \mathrm{mM} \mathrm{NaHCO}$. Quantification was achieved using 179 external standards.

180

181 Data analyses

182 Unless otherwise reported, all values represent mean \pm standard deviation (SD). For 183 correlation between land usage and concentration of pesticides, Pearson correlation 184 coefficients were used for evaluating the relation between nitrate and pesticide concentration, 185 relation of atrazine and degradation products (using their molar ratios), and pesticide and 186 nitrate concentration and land use. For the latter purpose, the mean total discharge of the 187 respective pesticides (and nitrate) from springs of the same geographical area was calculated 188 and plotted against the respective land usage in \%. For all correlations, both slope and 189 intercept were considered. A P-value<0.05 (2-sided) was considered statistically significant.

191 Results

192 Spring water locations

193 The most common pesticide derived compound was 2,6-dichlorobenzamide, a degradation 194 product of dichlobenil (Table 2), and detectable in the majority of springs. Atrazine and/or 195 degradation products (DEA and DIA) were also detected in most springs, and concentrations 196 were similar during the entire 2-year period and the 10 campaigns (Figure 4), with no 197 detectable global trend. The major molecule of the s-triazine herbicides and their degradation 198 products found was DEA, followed by atrazine and DIA (Table 2). Simazine was detected in 199 traces while other s-triazine-herbicides, including cyanazine, sebuthylazine, and hexaxinon 
200 were not detected in any of the samples. Only 4 springs were completely free of detectable 201 pesticides.

202 The range of land usage varied from 1.7 to 38.8 cropland (average 16.1\% (Ministère de 203 l'Environnement Luxembourg, 1999)), and from 3.2 to 26.6\% (mean 15.4\%) for urban usage, 204 with a clear correlation between nitrate and cropland $(\mathrm{R}=0.86, \mathrm{P}<0.05)$. A low but significant 205 correlation between the usage of land as cropland and concentration of DEA was found $206(\mathrm{R}=0.44, \mathrm{p}<0.001)$, with lower positive correlations for atrazine and DIA. Interestingly, a high 207 correlation between BAM and urban land use was found $(\mathrm{R}=0.81, \mathrm{P}<0.05)$. When 208 investigating the ratio between DEA and atrazine (expressed on a molar basis, Figure 5), a 209 ratio that has been used to discriminate between point-source contamination and non-point 210 source contamination (Scribner et al., 2005), most springs plotted on a regression line with a 211 mean slope of ca. $2.8(\mathrm{R}=0.94)$. However, a second group of measurements was determined 212 with a slope of approximately $0.3(\mathrm{R}=0.95)$, belonging to a group of 6 springs located 213 together, and associated with low cropland usage (3.4\%), but a comparatively high urban 214 coverage $(16.8 \%)$. When plotting atrazine vs. nitrate, a similar pattern with the same 2 groups 215 of springs was revealed, with a ratio of atrazine $(\mathrm{pmol} / \mathrm{L})$ : nitrate $(\mathrm{mg} / \mathrm{L})$ of $>\mathrm{ca} .3 .4$, 216 indicative for the 6 springs. BAM and nitrate were only very weakly correlated $(\mathrm{R}=0.11)$. 217 Nitrate range was between 3.8 and 78.1 (mean 31.5) $\mathrm{mg} / \mathrm{L}$ for all springs. In addition, a high 218 ratio of DIA:DEA was reported to indicate that other DIA precursors such as cyanazine and 219 simazine were present (Scribner et al., 2005). In the present investigation, the DIA:DEA ratio 220 was generally below 1 , mostly below 0.5 .

222 Tap water

223 Tap water was collected at a number of locations ( $n=15$ villages or cities, with each 1-5 224 sampling locations) in Luxembourg. Again, DEA was the predominant s-triazine herbicide 
225 derivative, found at concentrations between 0-62 (mean: 14)ng/L, followed by atrazine with $2260-44$ (mean: 4)ng/L and DIA, ranging from 0-6 ng/L, with a sum of atrazine, DEA and DIA 227 of 0-111 (mean 18)ng/L (Figure 6). Only 2 out of 15 sampling locations were negatively 228 tested for atrazine and degradation products. Tap water concentrations for southern 229 Luxembourg (defined here as all locations and including those south of Luxembourg City) 230 were lower in atrazine and degradation products DEA and DIA (13 ng/L) compared to those 231 north of Luxembourg City (37 ng/L); however, results were not significantly different. BAM 232 (5 from 15 sampling locations negative) was the only other herbicide detected, with 233 concentrations of $0-96$ (mean: 13)ng/L, except for terbuthylazine, which was found in one 234 occasion at ca. $1 \mathrm{ng} / \mathrm{L}$.

\section{Bottled water}

237 Due to the limited number of brands available in Luxembourg, 7 Luxembourgish water 238 varieties, with $(\mathrm{n}=2)$ and without carbon dioxide, from 2 major companies and areas were 239 investigated. In addition, 3 French brands commonly traded and consumed in Luxembourg, 240 were investigated (Table 3). From the $n=14$ Luxembourgish samples investigated, only 1 241 contained measurable amounts of atrazine (no degradation products), with a content of ca. 1.5 $242 \mathrm{ng} / \mathrm{L} .2$ of the French brands were also negative, but the third one ( $\mathrm{n}=3$ samples) contained 243 measurable amounts of atrazine. Overall mean concentrations for atrazine were 1(range 0244 4)ng/L, and degradation products DEA (2, range 0-11ng/L) and DIA (2, range 0-7ng/L). In 245 addition to these, only BAM could be detected in 4 out of 25 samples (all originating from 246 Luxembourg), with average concentrations of 2(range 0-14)ng/L. 


\section{Discussion}

249 In the present study, we have demonstrated that despite its ban in 2004, low but measurable 250 concentrations of the s-triazine herbicides atrazine, and its degradation products DEA and 251 DIA were detectable in the majority of spring waters from Luxembourg City, and at similar 252 concentrations at most tap water locations, but were almost absent in bottled water from 253 Luxembourg, being the first study reporting values for Luxembourg from unfinished and 254 finished drinking water. It also is suggested that the ratio of atrazine:nitrate, in addition to the 255 ratio of DEA:atrazine could be used to differentiate between non-point-source agricultural 256 contamination of atrazine and non-agricultural contamination, also detected in the present 257 study. Other s-triazine herbicide contamination was negligible by comparison.

258 Usage of atrazine had been officially declared illegal by individual states, as in Germany 259 (1991) or France (2002), before being eventually banned EU-wide and thus also in 260 Luxembourg in 2004. However, also in countries where atrazine was banned for a 261 comparably long time, still significant concentrations of the parent compound and its main 262 bacterial breakdown products, DEA and DIA can be detected, with concentrations of DEA 263 typically surpassing that of atrazine. For example, in Bavaria, Germany, approx. 5\% of 264 sampling points had concentrations of $>0.1 \mu \mathrm{g} / \mathrm{L}$ atrazine and DEA, and in almost $50 \%$ of the 265 sampling points either DEA, atrazine, or both could be detected in 1999, 8 years after the 266 atrazine ban (Tappe et al., 2002). In countries where atrazine is still in use, such as the US, 267 concentrations are even higher, with atrazine peak concentrations in raw water of up to 230 $268 \mu \mathrm{g} / \mathrm{L}(\mathrm{Wu}$ et al., 2010). The long persistence of these compounds is related to the long half-

269 life of atrazine and their de-alkylated metabolites DEA and DIA in deeper soil layers or water, 270 with half-lives of atrazine and DEA around 28-178 days (Krutz et al., 2010), with shorter 271 half-lives in surface and especially adapted soils, i.e. soils that were regularly treated with s272 triazines (Krutz et al., 2010). As DEA is more polar and about 20 times more water soluble 
273 (Scribner et al., 2005), it was suggested to bind less strongly to the soil than atrazine, 274 therefore resulting in higher concentration in groundwater, in which degradation is impeded 275 due to lower bacteria counts that could result in degradation (Scribner et al., 2005). DIA conversion rate from atrazine is low compared to DEA, explaining its lower abundance in the 277 environment (Krutz et al., 2010).

278 The spring water concentrations in the present study, ranging from $0-57 \mathrm{ng} / \mathrm{L}$ for atrazine, and $2790-120 \mathrm{ng} / \mathrm{L}$ for its degradation product DEA were generally, but not always $(7$ cases $>0.1$ $280 \mu \mathrm{g} / \mathrm{L}$ DEA) in agreement with EU directive 98/83/EC (even though defined for finished 281 water), demanding a concentration of a single pesticide below $0.1 \mu \mathrm{g} / \mathrm{L}$. The sum parameter 282 of $<0.5 \mu \mathrm{g} / \mathrm{L}$ required by the same EU directive was not violated. Older data from 283 Luxembourgish groundwater from various aquifers ( $\mathrm{n}=72$ locations from various regions) 284 from 2005 and older (Administration de la Gestion de l'Eau, 2005) indicated similar, even 285 slightly higher concentrations for atrazine (range 0-550 ng/L, mean $16 \mathrm{ng} / \mathrm{L}$ ) and DEA (range $2860-158 \mathrm{ng} / \mathrm{L}$, mean $16 \mathrm{ng} / \mathrm{L})$, although DEA was not detected in the majority of groundwater 287 sampling points by then (47 negative out of 72), nevertheless highlighting their long 288 persistence.

289 The only other herbicide or derivative with notable concentrations detected was BAM, a 290 degradation product of dichlobenil, with concentrations of up to $346 \mathrm{ng} / \mathrm{L}$. Dichlobenil has 291 been applied mainly for lawns and gardens. As it was also found to be persistent in the 292 groundwater, it has meanwhile also been banned in EU countries, including Luxembourg in 2932010 (EU Commission, 2008). Its endocrine disrupting potential is currently not understood,

294 but it has been found to affect reproduction in animals (Cox, 1997), and constitutes the major 295 groundwater contaminant in other EU countries (Holtze et al., 2008). In the present 296 investigation, BAM was found in 51 spring water samples (out of ca. 700) to surpass the 0.1 $297 \mu \mathrm{g} / \mathrm{L}$ EU limit slightly. In addition, these high concentrations were only found in few 
298 individual springs, which are usually not consumed unpooled. After pooling of various water 299 sources, including additional water from northern Luxembourg as is typical for Luxembourg300 City, concentrations might be more likely to fall below $0.1 \mu \mathrm{g} / \mathrm{L}$.

301 While DEA, the major s-triazine degradation compound detected, can be formed from 302 atrazine and propazine (a less frequently used herbicide in Europe), DIA can be formed from 303 atrazine, simazine, or cyanazine. Thus, a high ratio (>0.6, (Scribner et al., 2005) of DIA:DEA 304 would indicate several parental sources of DIA. However, this ratio was almost never reached 305 in the present investigation (only in 3 out of ca. 700 point measurements), indicating, in 306 addition to the actual low measured concentrations, that simazine and cyanazine were much 307 less frequently used herbicides compared to atrazine.

308 Another ratio that has been employed is DEA:atrazine, with a low ratio (ca. 0.5) suggesting 309 point-source contamination, as otherwise, due to its increased formation in soil over time 310 from atrazine (due to microbiological activity), DEA concentrations would tend to be higher. 311 Thus, the DEA:atrazine ratio was used as an indicator of point-source contamination 312 (Scribner et al., 2005) perhaps suggesting non-agricultural usage of atrazine, even though 313 additional methods, including several geostatistic approaches (Leterme et al., 2006) have 314 aimed to differentiate between point and non-point contamination. In the present study, we 315 recognized that by using this cut-off ratio (0.5), 6 springs located together possessed such a 316 remarkably lower ratio, indicating point-source contamination. In addition, the same springs 317 showed also lower nitrate concentrations and a ratio of atrazine (pmol/L): nitrate $(\mathrm{mg} / \mathrm{L})>3.4$, 318 also suggesting that the atrazine source was not linked to general agricultural farming 319 practices, and that the ratio of atrazine to nitrate could be an additional suitable marker to 320 differentiate between non-point-source agricultural use and other applications. A correlation 321 between nitrate and atrazine has already been noted earlier (Umweltbundesamt Oesterreich, 322 2005). 
323 Interestingly, the poor correlation of BAM and nitrate and the high correlation between BAM 324 and urban land usage suggested that dichlobenil was not necessarily originating from 325 agricultural use. However, despite the indication of local atrazine contamination sources, the 326 positive correlation of crop land use and DEA concentration indicated that agriculture was, in 327 general, the major source of contamination for atrazine.

328 Correspondingly to the spring water contamination with atrazine, tap water also clearly 329 showed the presence of atrazine and its metabolites DEA and DIA. Tap water contamination 330 was also reported for other countries, including the US (up to $60 \mu \mathrm{g} / \mathrm{L}$, Wu et al., 2010), 331 China (Gfrerer et al., 2002), and France, where atrazine and DEA surpassed in ca. 1\% of the 332 investigated drinking water $0.1 \mu \mathrm{g} / \mathrm{L}$ (Ministère de la Santé et des Solidarités, 2005), in some 333 areas such as the Alsace, with even $>13 \%$ (atrazine) and $>17 \%$ (DEA, 334 http://vorort.bund.net/suedlicher-oberrhein/wasser-oberrhein.html). Concentrations in the 335 present study were all below this concentration; however, individual concentrations varied 336 considerably, with some places showing concentrations just below the EU requirement, with 337 up to $208 \mathrm{ng} / \mathrm{L}$ for the sum of detected pesticides including their degradation products and up 338 to $96 \mathrm{ng} / \mathrm{L}$ for individual pesticides or their derivatives, i.e. BAM, emphasizing the 339 importance of continuous efforts to further lower their concentration in drinking water and 340 monitor drinking water locally to observe changes of these contaminants over longer periods 341 of times. Processes that are used for preparing drinking (tap) water typically include 342 chlorination, flocculation, sedimentation, filtration, followed by a second disinfection stage 343 such as chlorination, UV, or ozonization. It has been shown in earlier reports that atrazine and 344 degradation products are quite resistant to these processes and are hardly removed (Benotti et $345 a l ., 2009)$. In our study, when comparing mean spring water contamination (unfinished water) 346 of atrazine and degradation products (sum $31 \mathrm{ng} / \mathrm{L}$ ) with mean tap water concentrations in 347 Luxembourg City (23 ng/L), only a slight reduction in s-triazine content could be assumed. 
348 However, the comparison is impeded by the fact that different locations were investigated,

349 and that tap water for Luxembourg City is diluted with drinking water from northern

350 Luxembourg.

351 Bottled water exhibited the lowest concentrations compared to individual spring water 352 locations and tap water, and does not seem to contribute considerably to intake of potential 353 EDC. The one positive sample produced in Luxembourg contained very low amounts of s354 triazine herbicides, below $1.5 \mathrm{ng} / \mathrm{L}$, interestingly, only atrazine. The absence or low pesticide 355 concentrations measured in those waters may be explained by the fact that they were obtained 356 from deeper or more remote groundwater sources, and that bottled water is typically 357 undergoing filtration through charcoal filters, a process which is known to bind and remove 358 pesticides, including s-triazine herbicides (Wu et al., 2010), a step which has not generally 359 been put into practice for tap water, partly due to its comparatively high costs.

360 When estimating a mean consumption of $2.1 \mathrm{~L}$ water per day and capita from various 361 beverage sources (Walti et al., 2005), with ca. 35\% coming from tap water, ca. 15\% bottled 362 water, and the remainder from various other sources (tea, coffee, fruit juices, sodas) that are 363 assumed to be low in s-triazine herbicides comparable to bottled water, and combine this 364 consumption pattern with mean triazine and degradation product concentrations obtained in 365 this study ( $\Sigma$ atrazine + DEA +DIA in tap and bottled water: $18 \mathrm{ng} / \mathrm{L}$ and ca. $2 \mathrm{ng} / \mathrm{L}$, 366 respectively), it can be estimated that via this route approx. $16 \mathrm{ng} /$ day s-triazine herbicides are 367 consumed in Luxembourg by its ca. 0.5 mio. inhabitants. Even though other food items may 368 contribute to atrazine intake (United States Department of Public Health and Human Services, 369 2003), water is assumed to be by far the most contributing source. An ADI (acceptable daily 370 intake) of $5 \mu \mathrm{g} / \mathrm{kg}$ body weight for atrazine has been suggested (National Registration 371 Authority, 1997), thus the estimated intake as determined in this study would be far lower. 
372 In conclusion, the large majority of pesticides and their degradation products measured in 373 water samples in Luxembourg were in accordance with European Regulations, emphasizing 374 that these safeguards were generally observed. Given that the environment is most often 375 polluted by several pollutants that could act in synergy, it would be prudent in the future to 376 continue measuring pesticides, their degradation products, and their intake, which is 377 especially important for pregnant women and infants, which are most prone to adverse effects 378 such as those caused by endocrine disruptor activity.

381 Acknowledgements

382 We thank Mr. Jean-Francois Iffly and Mr. François Barnich for aiding in the water collection, 383 Ms. Johanna Ziebel for helping in the pesticide measurements, Ms. Sonia Heitz for 384 cartographic assistance and Mr. N. Pundel and Mr. G. Zimmer from the "Service des Eaux de 385 la Ville de Luxembourg" for their advice and cooperation for the planning of the study. We 386 further appreciate the critical reading by Dr. Laurent Pfister. We are grateful for the FNR 387 grant support within the SECAL call, grant no. 030705. 
References

1. Administration de la Gestion de l'Eau [Internet]; [cited 2010 Sept 19]. Available from: http://gis.eau.etat.lu/\#

401

402

403

404

405

406

407

408

409

410

411

412

413

414

415

416

417

418

419

420

421

422

423

424

425

426

427

428

429

430

431

432

2. Baker SE, Barr DB, Driskell WJ, Beeson MD, Needham LL. 2000. Quantification of selected pesticide metabolites in human urine using isotope dilution high-performance liquid chromatography/tandem mass spectrometry. J Expo Anal Environ Epidemiol. 10: 789-798.

3. Benotti MJ, Trenholm RA, Vanderford BJ, Holady JC, Stanford BD, Snyder SA. 2009. Pharmaceuticals and endocrine disrupting compounds in U.S. drinking water. Environ Sci Technol. 43: 597-603.

4. Betancourt M, Resendiz A, Fierro EC. 2006. Effect of two insecticides and two herbicides on the porcine sperm motility patterns using computer-assisted semen analysis (CASA) in vitro. Reprod Toxicol. 22: 508-512.

5. Bray LD, Szarka AZ, Heard NE, Hackett DS, Kahrs RA. 2008. Dietary exposure assessment of the triazine herbicides. In: HM Le Baron, JE McFarland and OC Burnside (Eds.). The Triazine Herbicides - 50 Years Revolutionizing Agriculture. Elsevier: Amsterdam, pp. 413-424.

6. Brignon JM. 2007. Atrazine. Metz, France, I N E R I S - Données technicoéconomiques sur les substances chimiques en France.

7. Brodkin MA, Madhoun H, Rameswaran M, Vatnick I. 2007. Atrazine is an immune disruptor in adult northern leopard frogs (Rana pipiens). Environ Toxicol Chem. 26: 8084.

8. Bundesministerium für Umwelt. 2005. Die Wasserrahmenrichtlinie - Ergebnisse der Bestandsaufnahme 2004 in Deutschland, 2. Auflage. Bonifatius: Paderborn.

9. Cederroth CR, Auger J, Zimmermann C, Eustache F, Nef S. 2010. Soy, phytooestrogens and male reproductive function: a review. Int J Androl. 33: 304-316.

10. Coban A, Filipov NM. 2007. Dopaminergic toxicity associated with oral exposure to the herbicide atrazine in juvenile male C57BL/6 mice. J Neurochem. 100: 1177-1187.

11. Cox C. 1997. Herbicide factsheet - dichlobenil. J Pest Ref. 17: 14-20.

12. Dionex Corporation. 1991. Determination of nitrite and nitrate in drinking water using ion chromatography with direct UV detection. Dionex Application Update AU 132.

13. EU Commission. 2008. COMMISSION DECISION of 18 September 2008 concerning the non-inclusion of dichlobenil in Annex I to Council Directive 91/414/EEC and the withdrawal of authorisations for plant protection products containing that substance. Official Journal of the European Union L 258: 70-81. 
14. Gfrerer M, Wenzl T, Quan X, Platzer B, Lankmayr E. 2002. Occurrence of triazines in surface and drinking water of Liaoning Province in Eastern China. J Biochem Biophys Meth. 53: 217-228.

15. Giraud F, Pasquali M, El-Jarroudi JM, Vrancken C, Brochot C, Cocco E, Hoffmann L, Delfosse P, Bohn T. 2010. Fusarium head blight and associated mycotoxin occurrence on winter wheat in Luxembourg in 2007/2008. Food Addit Contam Part A Chem Anal Control Expo Risk Assess. 27: 825-835.

16. Gourdol L, Zimmer G, Pundel N, Pfister L, Hoffmann L. 2010. Les sources de la ville de Luxembourg : une ressource en eau potable à préserver. Arch Sci Nat Phys Math. NS 45: 101-124.

17. Hayes TB, Khoury V, Narayan A, Nazir M, Park A, Brown T, Adame L, Chan E, Buchholz D, Stueve T, Gallipeau S. 2010. Atrazine induces complete feminization and chemical castration in male African clawed frogs (Xenopus laevis). Proc Natl Acad Sci USA 107: 4612-4617.

18. Hayes TB, Stuart AA, Mendoza M, Collins A, Noriega N, Vonk A, Johnston G, Liu R, Kpodzo D. 2006. Characterization of atrazine-induced gonadal malformations in African clawed frogs (Xenopus laevis) and comparisons with effects of an androgen antagonist (cyproterone acetate) and exogenous estrogen (17 beta-estradiol): Support for the demasculinization/feminization hypothesis. Environ Health Perspect. 114 (Suppl 1): 134-141.

19. Holtze MS, Sørensen SR, Sørensen J, Aamand J. 2008. Microbial degradation of the benzonitrile herbicides dichlobenil, bromoxynil and ioxynil in soil and subsurface environments - Insights into degradation pathways, persistent metabolites and involved degrader organisms. Environ Pollut. 154: 155-168.

20. Jason KL, Shaner DL, Weaver MA, Webb RM, Zablotowicz RM, Reddy KN, Huang Y, Thomson SJ. 2010. Agronomic and environmental implications of enhanced s-triazine degradation. Pest Manag Sci. 66: 461-481.

21. Kniewald J, Jakominic M, Tomljenovic A, Simic B, Romac P, Vranesic D, Kniewald Z, 2000. Disorders of male rat reproductive tract under the influence of atrazine. J Appl Toxicol. 20: 61-68.

22. Krutz JL, Shaner DL, Weaver MA, Webb RM, Zablotowicz RM, Reddy KN, Huang Y, Thomson SJ. 2010. Agronomic and environmental implications of enhanced s-triazine degradation. Pest Manag Sci. 66: 461-481.

23. Kuster M, Diaz-Cruz S, Rosell M, Lopez de AM, Barcelo D. 2010. Fate of selected pesticides, estrogens, progestrogens and volatile organic compounds during artificial aquifer recharge using surface waters. Chemosphere 79: 880-886.

24. Lasserre JP, Fack F, Revets D, Planchon S, Renaut J, Hoffmann L, Gutleb AC, Muller CP, Bohn T. 2009. Effects of the endocrine disruptors atrazine and PCB 153 on the protein expression of MCF-7 human cells. J Proteome Res 8: 5485-5496.

25. Leistra M, Boesten JJTI. 1989. Pesticide contamination of groundwater in western Europe. Agric Ecosys Environ. 26: 369-389. 
26. Leterme B, Vanclooster M, Rounsevell MDA, Bogaert P. 2006. Discriminating between point and non-point sources of atrazine contamination of a sandy aquifer. Sci Total Environ. 362: 124-142.

27. Loos R, Locoro G, Comero S, Contini S, Schwesig D, Werres F, Balsaa P, Gans O, Weiss S, Blaha L, Bolchi M, Gawlik BM. 2010. Pan-European survey on the occurrence of selected polar organic persistent pollutants in ground water. Water Res. 44: 41154126.

28. Mantovani A, Frazzoli C, La RC. 2009. Risk assessment of endocrine-active compounds in feeds. Vet J. 182: 392-401.

29. Ministère de l'Environnement Luxembourg. 1999. Occupation Biophysique du Sol du Grand-Duché de Luxembourg. Ministère de l'Environnement Luxembourg.

30. Ministère de la Santé et des Solidarités. 2005. Dossier d'Information: La qualité de l'eau potable en France. Aspects sanitaires et réglementaires. Ministère de la Santé et des Solidarités, Direction Générale de la Santé, France.

31. Mirgain I, Schenck C, Monteil H. 1993. Atrazine contamination of groundwaters in eastern France in relation to the hydrogeological properties of the agricultural land. Environ Technol. 14: 741-750.

32. National Registration Authority. 1997. The NRA Review of Atrazine. Canberra: National Registration Authority, Australia.

33. Pailler JY, Guignard C, Meyer B, Iffly JF, Pfister L, Hoffmann L, Krein A. 2009. Behaviour and fluxes of dissolved antibiotics, analgesics and hormones during flood events in a small heterogeneous catchment in the Grand Duchy of Luxembourg. Water Air Soil Pollut. 203: 79-98.

34. Panuwet P, Nguyen JV, Kuklenyik P, Udunka SO, Needham LL, Barr DB. 2008. Quantification of atrazine and its metabolites in urine by on-line solid-phase extractionhigh-performance liquid chromatography-tandem mass spectrometry. Anal Bioanal Chem. 391: 1931-1939.

35. Papiernik SK, Spalding RF. 1998. Atrazine, deethylatrazine, and deisopropylatrazine persistence measured in groundwater in situ under low-oxygen conditions. J Agric Food Chem. 46: 749-754.

36. Planas C, Puig A, Rivera J, Caixach J. 2006. Analysis of pesticides and metabolites in Spanish surface waters by isotope dilution gas chromatography/mass spectrometry with previous automated solid-phase extraction. Estimation of the uncertainty of the analytical results. J Chromatogr A 1131: 242-252.

37. Ralston-Hooper K, Hardy J, Hahn L, Ochoa-Acuna H, Lee LS, Mollenhauer R, Sepulveda MS. 2009. Acute and chronic toxicity of atrazine and its metabolites deethylatrazine and deisopropylatrazine on aquatic organisms. Ecotoxicology 18: 899905. 
38. Rayner JL, Wood C, Fenton SE. 2004. Exposure parameters necessary for delayed puberty and mammary gland development in Long-Evans rats exposed in utero to atrazine. Toxicol Appl Pharmacol. 195: 23-34.

39. Ribaudo MO, Bouzaher A. 2010. Atrazine: Environmental Characteristics and Economics of Management. Agricultural Economic Report Number 699. Washington, D.C.: USDA.

40. Rodriguez VM, Thiruchelvam M, Cory-Slechta DA. 2005. Sustained exposure to the widely used herbicide atrazine: altered function and loss of neurons in brain monoamine systems. Environ Health Perspect. 113: 708-715.

41. Rowe AM, Brundage KM, Barnett JB. 2008. Developmental immunotoxicity of atrazine in rodents. Basic Clin Pharmacol Toxicol. 102: 139-145.

42. Scribner EA, Thurman EM, Goolsby DA, Meyer MT, Battaglin WA, Kolpin DW. 2005. Summary of significant results from studies of triazine herbicides and their degradation products in surface water, and precipitation in the midwestern United States during the 1990s. Washington D.C.: US Department of the Interior, US. Geological Survey.

43. Shomar B, Müller G, Yahya A. 2006. Occurrence of pesticides in groundwater and topsoil of the Gaza Strip. Water Air Soil Pollut. 171: 237-251.

44. Solomon KR. 2009. Is atrazine a potent endocrine disruptor chemical? Environ Sci Technol. 43: 2993.

45. Tappe W, Groeneweg J, Jantsch B. 2002. Diffuse atrazine pollution in German aquifers. Biodegradation. 13: 3-10.

46. Tavera-Mendoza L, Ruby S, Brousseau P, Fournier M, Cyr D, Marcogliese D. 2002. Response of the amphibian tadpole (Xenopus laevis) to atrazine during sexual differentiation of the testis. Environ Toxicol Chem. 21: 527-531.

47. Thurman EM, Scribner EA. 2008. A decade of measuring, monitoring, and studying the fate and transport of triazine herbicides in groundwater, surface water, reservoirs, and precipitation by the U.S. Geological Survey. In: HM LeBaron, J McFarland and O Burnside (Eds.). The Triazine Herbicides. Amsterdam: Elsevier Science.

48. Trenholm RA, Vanderford BJ, Holady JC, Rexing DJ, Snyder SA. 2006. Broad range analysis of endocrine disruptors and pharmaceuticals using gas chromatography and liquid chromatography tandem mass spectrometry. Chemosphere 65: 1990-1998.

49. Umweltbundesamt Oesterreich. Datenbank Porengrundwasser [Internet]. 2006.

Umweltbundesamt; [cited 2010 Sept 9]. Available from:

http://eweb.umweltbundesamt.at/eGWBericht2006/pdf/Parameterinformation/Atrazin_ Desethylatrazin/G192_G193.pdf

50. United States Department of Public Health and Human Services. 2003. ATSDR Toxicological Profile for Atrazine. Atlanta (GA): United States Department of Public Health and Human Services. 
550

551

552

553

554

555

556

557

558

559

560

561

562

563

564

565

566

567

568

569

570

571

572

573

574

575

576

577

578

579

580

581

582

583

51. Vogue PA, Kerle EA, Jenkins JJ. OSU Extension Pesticide Properties Database [Internet]. OSU; [cited 2010 August 16]. Available from:

http://npic.orst.edu/ppdmove.htm

52. Walti M, Wenk C, Colombani PC. 2005. Mineralstoff-und Flüssigkeitszufuhr über Getränke bei Erwachsenen in der Schweiz. In: M Eichholzer, E Camenzind-Frey, A Matzke and R Amado (Eds.). Fünfter Schweizerischer Ernährungsbericht. Bern: Bundesamt für Gesundheit, pp. 37-50.

53. Wu M, Quirindongo M, Sass J, Wetzler A. 2010. Still Poisoning the Well: Atrazine Continues to Contaminate Surface Water and Drinking Water in the United States. New York: Natural Resources Defense Council. 
585 Figure Captions:

586

587 Figure 1: Pesticides and degradation products monitored during sampling campaigns in 588 Luxembourg between summer 2007 and spring 2009.

589

590 Figure 2: Locations of spring water $(n=69$, circles in map) included for pesticide analyses 591 from Luxembourg City between summer 2007 and spring 2009. All spring water locations 592 used for drinking water supply in Luxembourg-City were included.

593

594 Figure 3: Locations of tap water sampling $(n=28)$ for determination of pesticides in 2008 595 (stars) and 2009 (triangles) in Luxembourg.

596

597 Figure 4 : Concentrations of major herbicides and degradation products detected in spring 598 water from Luxembourg City $(n=69)$ between summer 2007 and spring 2009. Values reflect 599 mean \pm SE. BAM=2,6 dichlorobenzamide, DEA=desethylatrazine, DIA=deisopropylatrazine.

600

601 Figure 5: Relation between atrazine, degradation products desethylatrazine (DEA), 602 deisopropylatrazine (DIA), and nitrate in Luxembourgish spring water $(n=69)$ during the 603 years 2007-2009 and 10 measurement campaigns.

604

605 Figure 6: Concentration of atrazine and degradation products desethylatrazine (DEA) and 606 deisopropylatrazine (DIA) in tap water from various locations in Luxembourg, collected in 607 spring 2008 and spring 2009. Concentrations shown are means of $n=1-5$ locations, depending 608 on the number of tap water locations investigated per location. 


\section{Table 1}

Retention time, parent mass, transition ions and collision energy and declustering potential for measuring pesticides following extraction of $500 \mathrm{~mL}$ of water samples for each pesticide and SRM conditions for the LC-MS-MS analyses in positive mode.

\begin{tabular}{|c|c|c|c|c|c|}
\hline pesticide & $\begin{array}{l}\text { retention time } \\
(\min )\end{array}$ & $\begin{array}{c}\text { parent ion } \\
(\mathrm{m} / \mathrm{z})\end{array}$ & $\begin{array}{l}\mathrm{DP}^{\mathrm{a}} \\
(\mathrm{V})\end{array}$ & $\begin{array}{c}\text { transition } 1 \mathrm{CE}^{\mathrm{b}} \\
(\mathrm{V})\end{array}$ & $\begin{array}{c}\text { transition } 2 \mathrm{CE}^{\mathrm{b}} \text { in } \\
(\mathrm{V})\end{array}$ \\
\hline atrazine & 12.39 & 216.1 & 49 & $174.2(22)$ & $104.0(40)$ \\
\hline desethylatrazine & 4.71 & 188.1 & 42 & $146.1(22)$ & $104.1(35)$ \\
\hline deisopropylatrazine & 2.60 & 174.1 & 70 & $68.0(42)$ & $104.0(30)$ \\
\hline simazine & 9.01 & 202.1 & 50 & $104.1(33)$ & $124.1(24)$ \\
\hline terbuthylazine & 14.76 & 230.1 & 52 & $174.1(24)$ & $104.0(43)$ \\
\hline sebuthylazine & 14.41 & 230.1 & 52 & $174.1(24)$ & $104.0(43)$ \\
\hline cyanazine & 9.67 & 241.1 & 50 & $214.1(24)$ & $104.1(40)$ \\
\hline hexaxinon & 8.40 & 253.1 & 50 & $171.1(50)$ & $71.0(50)$ \\
\hline isoproturon & 13.15 & 207.2 & 44 & $72.0(40)$ & $165.1(19)$ \\
\hline chlortoluron & 11.95 & 213.1 & 38 & $72.0(37)$ & $140.0(32)$ \\
\hline monolinuron & 12.91 & 215.0 & 38 & $125.9(25)$ & $99.0(47)$ \\
\hline methabenzthiazuron & 11.50 & 222.1 & 39 & $165.1(22)$ & $150.1(44)$ \\
\hline metoxuron & 8.04 & 229.1 & 46 & $72.0(8)$ & $229.1(22)$ \\
\hline diuron & 13.20 & 233.1 & 38 & $72.0(37)$ & $233.1(34)$ \\
\hline linuron & 14.87 & 249.0 & 35 & $160.0(24)$ & $132.9(47)$ \\
\hline metobromuron & 13.77 & 259.0 & 36 & $170.1(23)$ & $90.9(47)$ \\
\hline metazachlor & 14.12 & 278.1 & 29 & $134.1(31)$ & $210.1(15)$ \\
\hline metolachlor & 15.59 & 284.2 & 39 & $252.1(21)$ & $176.2(33)$ \\
\hline 2,6- dichlorobenzamide & 3.30 & 190.0 & 44 & $109.0(50)$ & $172.9(23)$ \\
\hline atrazine-d5 (IS) $^{\mathrm{c}}$ & 12.26 & 221.2 & 40 & $179.2(24)$ & - \\
\hline \multicolumn{6}{|c|}{${ }^{\mathrm{a}} \mathrm{DP}$, declustering potential } \\
\hline
\end{tabular}




\section{Table 2.}

Pesticides monitored in Luxembourgish spring water $(n=69)$, number of findings above limit of detection* and concentrations between summer 2007 and spring 2009.

\begin{tabular}{|c|c|c|c|c|c|}
\hline pesticide & $\begin{array}{l}\text { locations with } \\
\text { detectable } \\
\text { concentration* } \\
\text { (n) }\end{array}$ & $\begin{array}{c}\text { analyses } \\
\text { with } \\
\text { detectable } \\
\text { concentrations } \\
(\%)\end{array}$ & $\begin{array}{c}\min \\
\text { conc. }\end{array}$ & $\begin{array}{l}\max \\
\text { conc. }\end{array}$ & $\begin{array}{l}\text { mean } \\
\text { conc. }\end{array}$ \\
\hline atrazine & 58 & 78.3 & 0 & 57 & 9 \\
\hline desethylatrazine & 59 & 82.6 & 0 & 120 & 19 \\
\hline deisopropylatrazine & 47 & 49.6 & 0 & 27 & 3 \\
\hline simazine & 27 & 24.9 & 0 & 5 & 1 \\
\hline terbuthylazine & 1 & 0.2 & 0 & 1 & 0 \\
\hline sebuthylazine & 0 & 0 & 0 & 0 & 0 \\
\hline cyanazine & 0 & 0 & 0 & 0 & 0 \\
\hline hexaxinon & 0 & 0 & 0 & 0 & 0 \\
\hline isoproturon & 11 & 2.0 & 0 & 5 & 0 \\
\hline chlortoluron & 11 & 10.9 & 0 & 6 & 0 \\
\hline monolinuron & 1 & 0.2 & 0 & 4 & 0 \\
\hline methabenzthiazuron & 0 & 0 & 0 & 0 & 0 \\
\hline metoxuron & 0 & 0 & 0 & 0 & 0 \\
\hline diuron & 7 & 4.5 & 0 & 11 & 0 \\
\hline linuron & 0 & 0 & 0 & 0 & 0 \\
\hline metobromuron & 0 & 0 & 0 & 0 & 0 \\
\hline metazachlor & 0 & 0 & 0 & 0 & 0 \\
\hline metolachlor & 0 & 0 & 0 & 0 & 0 \\
\hline 2,6- dichlorobenzamide & 58 & 79.9 & 0 & 346 & 30 \\
\hline$\sum \mathrm{ATZ}+\mathrm{DEA}+\mathrm{DIA} * *$ & 61 & 83.5 & 0 & 202 & 32 \\
\hline$\sum$ all pesticides & 65 & 89.4 & 0 & 352 & 63 \\
\hline
\end{tabular}




\begin{tabular}{|c|c|c|c|c|c|c|}
\hline No. & Origin & $\mathrm{n}^{+}$ & Type & $\begin{array}{c}\text { atrazine } \\
(\mathrm{ng} / \mathrm{L})\end{array}$ & $\begin{array}{l}\mathrm{DEA}^{\&} \\
(\mathrm{ng} / \mathrm{L})\end{array}$ & $\begin{array}{l}\text { others } \\
\text { (ng/L) }\end{array}$ \\
\hline 1 & $\begin{array}{l}\text { Luxembourg, north } \\
\text { (Canton Echternach) }\end{array}$ & 1 & sparkling & n.d.* & n.d. & n.d. \\
\hline 2 & $\begin{array}{l}\text { Luxembourg, north, } \\
\text { (Canton Echternach) }\end{array}$ & 3 & weakly sparkling & n.d. & n.d. & n.d. \\
\hline 3 & $\begin{array}{l}\text { Luxembourg, north, } \\
\text { (Canton Echternach) }\end{array}$ & 3 & non-sparkling & n.d. & n.d. & $11.9 \pm 2.4 * *$ \\
\hline 4 & $\begin{array}{l}\text { Luxembourg, west, } \\
\text { (Canton Redingen) }\end{array}$ & 4 & non-sparkling & $0.4 \pm 0.7^{\$}$ & n.d. & $3.3 \pm 3.7 * *$ \\
\hline 5 & $\begin{array}{l}\text { Luxembourg, west, } \\
\text { (Canton Redingen) }\end{array}$ & 1 & non-sparkling & n.d. & n.d. & n.d. \\
\hline 6 & $\begin{array}{l}\text { Luxembourg, west, } \\
\text { Canton Redingen }\end{array}$ & 1 & non-sparkling & n.d. & n.d. & n.d. \\
\hline 7 & $\begin{array}{l}\text { Luxembourg, west, } \\
\text { (Canton Redingen) }\end{array}$ & 2 & non-sparkling & n.d. & n.d. & n.d. \\
\hline 8 & $\begin{array}{l}\text { France, } \\
\text { (Haute-Savoie) }\end{array}$ & 3 & non-sparkling & n.d. & n.d. & n.d. \\
\hline 9 & $\begin{array}{l}\text { France, } \\
\text { (Alsace-Lorraine) }\end{array}$ & 2 & non-sparkling & n.d. & n.d. & n.d. \\
\hline \multirow[t]{2}{*}{10} & $\begin{array}{l}\text { France, } \\
\text { (Auvergne) }\end{array}$ & 5 & non-sparkling & $2.7 \pm 0.9$ & $9.2 \pm 1.4$ & $\begin{array}{c}6.2 \pm 1.1 * * * \\
0.1 \pm 0.1 * *\end{array}$ \\
\hline & mean s-triazines & & & 0.3 & 0.9 & 1.8 \\
\hline \multicolumn{7}{|c|}{$\begin{array}{l}{ }^{+} \text {number of samples from each variety. Each purchased variety was investigated in duplicate } \\
* \text { n.d. = not detected } \\
* * 2,6 \text {,-dichlorobenzamide } \\
* * * \text { DIA }=\text { deisopropylatrazine }\end{array}$} \\
\hline
\end{tabular}


<smiles>CCNc1nc(Cl)nc(NC(C)C)n1</smiles>

atrazine<smiles>CC(C)Nc1nc(N)nc(Cl)n1</smiles>

desethyl-atrazine (DEA)<smiles>CCNc1nc(N)nc(Cl)n1</smiles>

desisopropyl-atrazine (DIA)<smiles>CCNc1nc(Cl)nc(NC(C)(C)C)n1</smiles><smiles>CCNc1nc(Cl)nc(NC(C)CC)n1</smiles>
sebuthylazine<smiles>CCNc1nc(Cl)nc(CC(C)(C#N)CCl)n1</smiles><smiles>CN(C)Cc1nc(=O)n(C2CCCCC2)c(=O)n1C</smiles><smiles>CC(C)c1ccc(NC(=O)N(C)C)cc1</smiles>
isoproturon<smiles>CNC(=O)N(C)C1Nc2ccccc2S1</smiles>
metabenzthiazuron<smiles>Cc1ccc(NC(=O)N(C)C)cc1Cl</smiles>

chlortoluron<smiles>COc1ccc(NC(=O)N(C)C)cc1Cl</smiles>

metoxuron<smiles>CON(C)C(=O)Nc1ccc(Cl)cc1</smiles>

monolinuron<smiles>CCc1cccc(C)c1N(C(=O)CCl)C(C)COC</smiles>

Figure 1: Pesticides and degradation products monitored during sampling campaigns in Luxembourg between summer 2007 and spring 2009. 


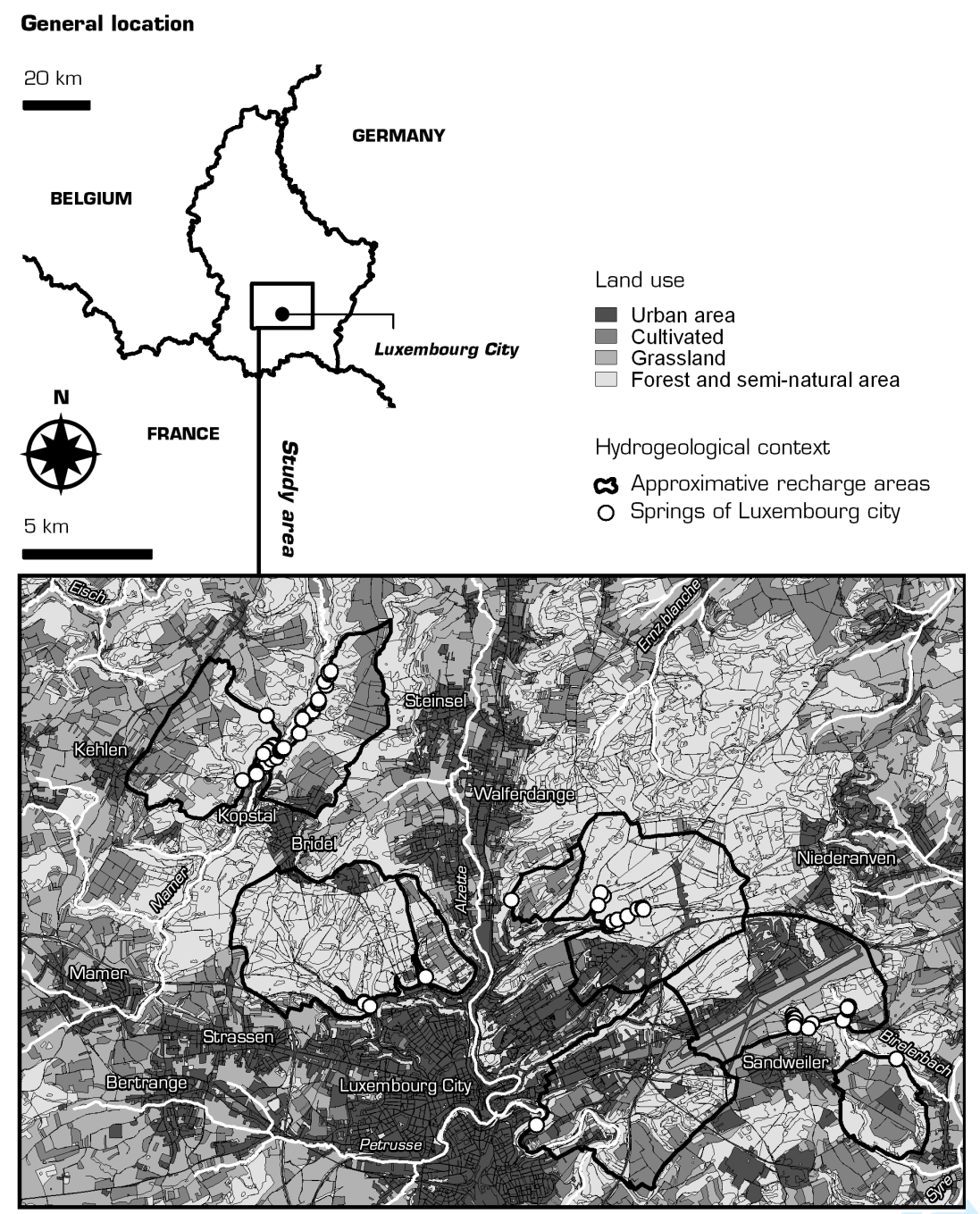

Figure 2: Locations of spring water ( $n=69$, circles in map) included for pesticide analyses from Luxembourg City between summer 2007 and spring 2009. All spring water locations used for drinking water supply in Luxembourg-City were included. 


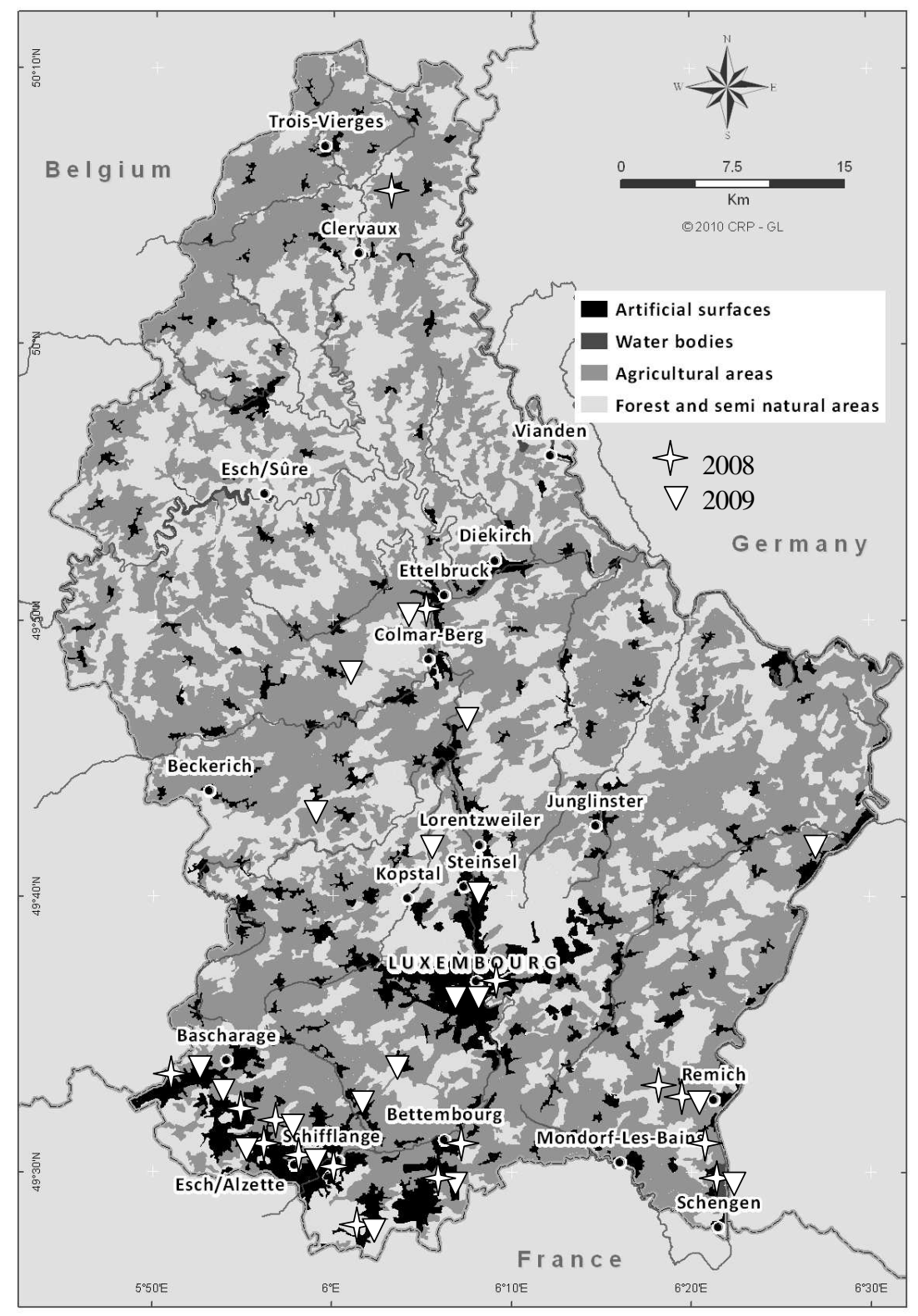

Figure 3: Locations of tap water sampling $(n=28)$ for determination of pesticides in 2008 (stars) and 2009 (triangles) in Luxembourg. 


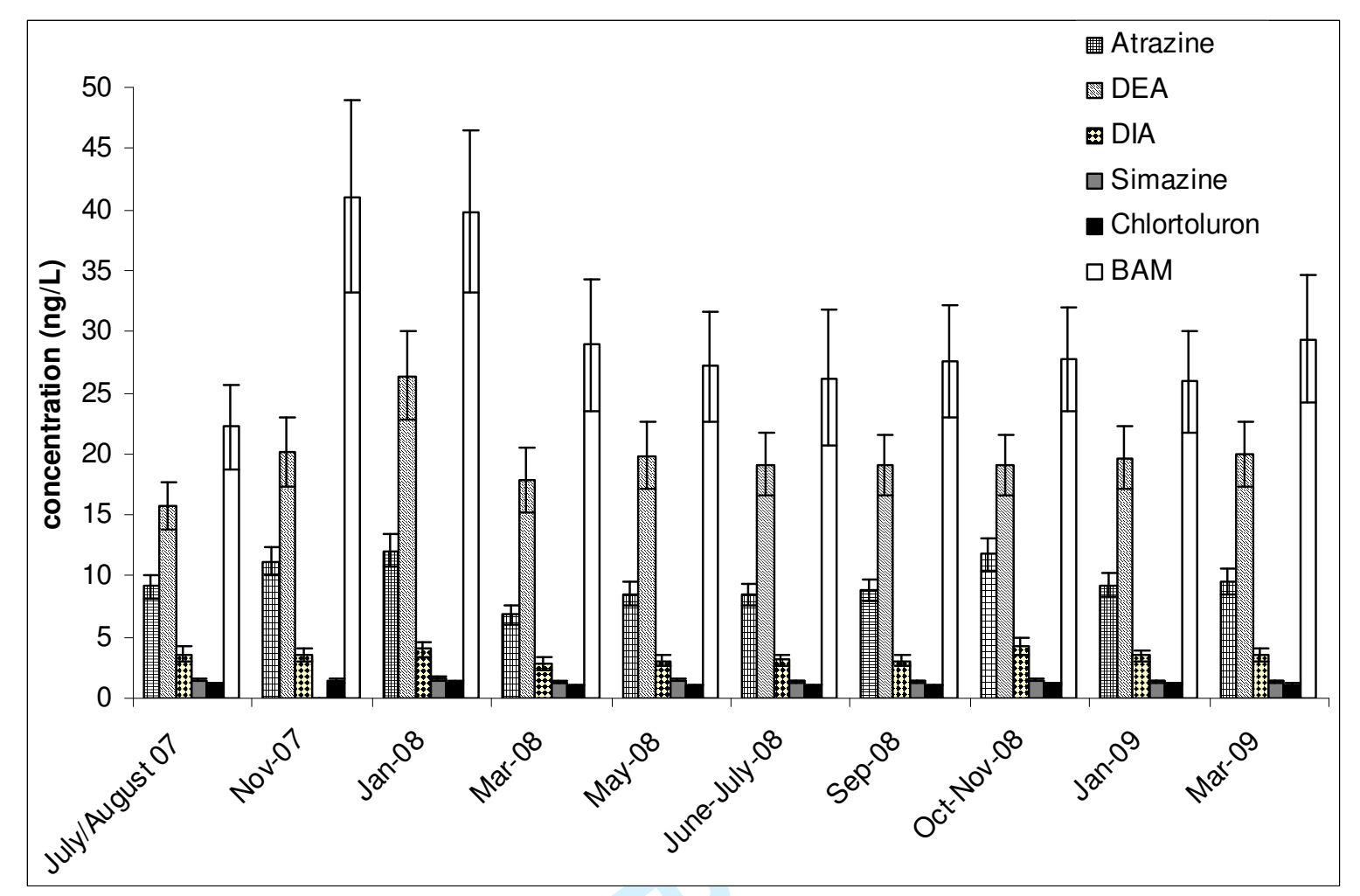

Figure 4 : Concentrations of major herbicides and degradation products detected in spring water from Luxembourg City $(n=69)$ between summer 2007 and spring 2009. Values reflect mean \pm SE. BAM=2,6 dichlorobenzamide, DEA=desethylatrazine, DIA=deisopropylatrazine. 

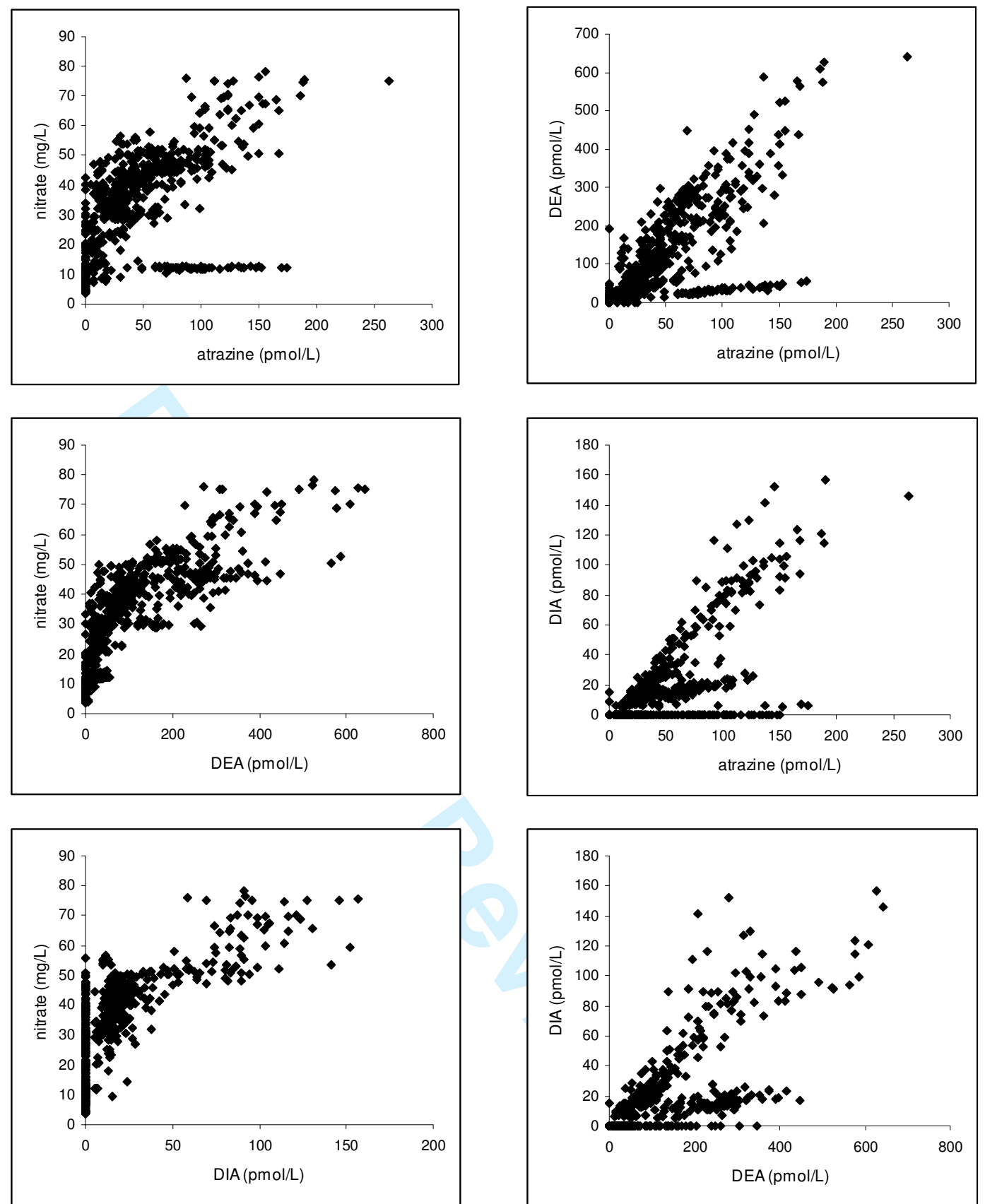

Figure 5: Relation between atrazine, degradation products desethylatrazine (DEA), deisopropylatrazine (DIA), and nitrate in Luxembourgish spring water $(n=69)$ during the years 2007-2009 and 10 measurement campaigns. 
Figure 6: Concentration of atrazine and degradation products desethylatrazine (DEA) and deisopropylatrazine (DIA) in tap water from various locations in Luxembourg, collected in spring 2008 and spring 2009. Concentrations shown are means of $n=1-5$ locations, depending on the number of tap water locations investigated per location. 